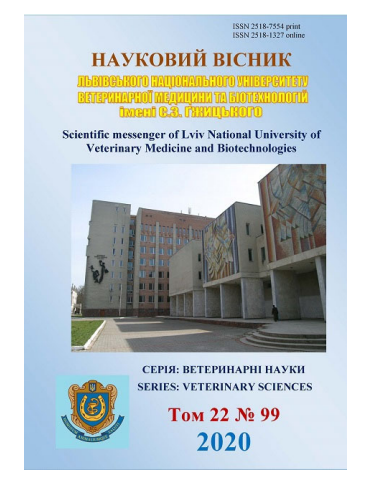

\author{
Науковий вісник Дьвівського національного університету \\ ветеринарної медицини та біотехнодогій імені С.3. Гжицыкого. \\ Серія: Ветеринарні науки \\ Scientific Messenger of Lviv National University \\ of Veterinary Medicine and Biotechnologies. \\ Series: Veterinary sciences
}

UDC 619:636.2.618.454

\title{
Cytology of smears of prints with symptomatic forms of infertility in cows
}

\author{
A. S. Revunets, S. B. Zarembliuk \\ Polissia National University, Zhytomyr, Ukraine
}

Article info

Received 16.09.2020 Received in revised form 15.10.2020

Accepted 16.10.2020

Polissia National University, Stary Boulevard, 7, Zhytomyr, 10002, Ukraine. Tel.: (0412) 33-39-50 E-mail: zaremblyk@ukr.net
Revunets, A. S., \& Zarembliuk, S. B. (2020). Cytology of smears of prints with symptomatic forms of infertility in cows. Scientific Messenger of Lviv National University of Veterinary Medicine and Biotechnologies. Series: Veterinary sciences, 22(99), 173-176. doi: 10.32718/nvlvet9926

Many works of domestic and foreign scientists are devoted to the study of etiological factors, pathogenesis, as well as the development of effective methods of diagnosis and therapy for symptomatic infertility of cows, however, insufficient attention is paid to cytological examination of the genital organs. So the goal of our work was to study the cytology of vaginal mucus at the symptomatic form of infertility of cows. The article presents the cytological composition of vaginal mucus from the mucous membrane of the caudal section of the cervix, the lateral surface of the vagina and the dorsal wall of the vaginal vestibule. Research was carried out with 5 groups of cows 4-5 years old cows 6 animals in each, weighing 500-600 $\mathrm{kg}$, with an average productivity of $7500 \mathrm{~kg}$ of milk per lactation. The tests were cows were on the 18-24 day after insemination and during the sexual cycle braking, research of the joint course of uterus and hypotension of the ovarian, the presence of persistent corpus luteum and subclinical chronic endometritis, cysts and persistent corpus luteum of the ovarian body. For sub-clinical chronic endometritis, basal cells $(32-41 \%)$ are found in wet prep with vaginal mucosa, which are arranged in layers, parabasal (22-6\%) and superficial (5-21\%), but more interstitial (37-66 \%), and bare neutrophil nuclei. According to hypofunction of ovaries in vaginal smears, neutrophils, vacuoles in interstitial cell nuclei (44-56\%), basophilic cells (30-43\%), superficial cells (20-21\%), parabasal cells (3-6\%). Basal cell hypofusions were (3-43\%), parabasal (3-6\%), interstitial (44-56\%), superficial (20-21\%), and bilateral (12-26\%) (4-5\%) (36-55\%) and (30-33\%). It should be noted that for the functional state of the body, the cells from the cervix are flat. In addition, the drug contains single white blood cells with light cytoplasm without signs of phagocytosis. They are structurally similar to cells of vaginal smear. During the esrtus, the smear is dominated by interstitial and surface cells and white cells, and in the follicular proliferative phase, the number of surface cells increases, while the ovulator phase is characterized by the pronounced maturation of the cells, they are flat and spaced apart.

Key words: symptomatic infertility, cows, vaginal smear, basophiles, neutrophils, parabasal cells, hypofunction of the ovaries, edometritis.

\section{Цитологія мазків відбитків за симптоматичної форми неплідності корів}

\author{
А. С. Ревунець, С. Б. Заремблюк
}

Поліський начіональний університет, м. Житомир, Украӥна

Багато робіт вітчизняних $і$ зарубіжних вчених присвячені вивченню етіологічних чинників, патогенезу, а також розробиі ефективних методів діагностики і терапії при симптоматичній неплідності корів, проте цитологічним дослідженням статевих органів автори приділяють недостатньо уваги. Тому метою нашої роботи було вивчення циитології вагінальної слизу при симптоматичній формі неплідності корів. В статті наведено иитологічний склад вагінального слизу із слизової оболонки каудального відділу шийки матки, бокової поверхні піхви і дорсальної стінки присінку піхви. Дослідження проводили на 5 групах корів 4-5річного віку по 6 голів у кожній, вагою 500-600 кг, середньою продуктивністю 7500 кг молока за лактацію. Контрольними були корови на 18-24 день після отелення і в стадії гальмування статевого ииклу, дослідними - за сумісного перебігу гіпотонії матки $і$ гіпофункиії яєчників, наявності персистентного жовтого тіла і субклінічного хронічного ендометриту, кісти та персистентного жовтого тіла яєчника. Встановлено, що за субклінічного хронічного ендометриту в мазках із слизової оболонки піхви присутні 
базальні клітини (32-41\%), щуо розташовані пластами, парабазальні (22-6\%) і поверхневі (5-21\%), але найбільще проміжних (37-66\%), та голі ядра нейтрофілів. За гіпофункції яєчників в піхвових мазках виявляли нейтрофіли, вакуолі в ядрах проміжних клітин (44-56\%), базофільні клітини (30-43\%), поверхневі (20-21\%), парабазальні (3-6\%). 3а гіпофункції яєчників базальних клітин було (3-43\%), парабазальних (3-6\%), проміжних (44-56\%), поверхневих (20-21\%) а при двобічній (12-26\%) - (4-5\%), (36-55\%) та (30-33\%). Варто зазначити, щуо за функціонального стану організму клітини із шийки матки плоскі. Окрім них, у препараті містяться одиничні лейкоцити зі світлою цуитоплазмою без ознак фагоцитозу. За структурою вони подібні до клітин мазків зі слизової оболонки піхви. Під час тічки в мазках переважають проміжні та поверхневі клітини і лейкоиити, а у фолікулярну проліферативну фазу, передтічкову, збільшується число поверхневих клітин, тимчасом як овуляторна фаза характеризується вираженим дозріванням клітин, вони плоскі та розташовуються порізно.

Ключові слова: симптоматична неплідність, корови, мазки, базофіли, нейтрофіли, парабазальні клітини, гіпофункиія яєчників, едометрит.

\section{Вступ}

На території України найбільшого поширеня набула симптоматична форма неплідності корів. У господарствах Житомирської області основними причинами якої $\epsilon$ запальні процеси у внутрішніх статевих органах, зокрема: гіпотонія та атонія матки - 36-40 \%, гіпофункція яєчників - 27-32\%, персистентне жовте тіло яєчників - 17-21\%, кісти яєчників - 16-19\%, сальпінгіт - 12-17 \%, склероз яєчників - 4-5 \%, атрофія і склероз яєчників - 6-8 \% (Hryshchuk \& Revunets, 2017).

Багато робіт вітчизняних i зарубіжних вчених (Causey, 2007; Azawi, 2008; Hoorens et al., 2011) присвячені вивченню етіологічних чинників, патогенезу, а також розробці ефективних методів діагностики i терапії при симптоматичній неплідності корів, проте цитологічним дослідженням статевих органів авторами приділяється недостатньо уваги.

Започатковане ще в 1916 р. дослідження мазків зі слизової оболонки піхви гризунів, а в 1923 році у жінок в менопаузі увійшло в клінічну гінекологічну практику і широко використовується тепер у гуманній медицині (Zegels et al., 2010).

Дослідження епітелію слизових оболонок різних відділів статевих органів корів використовують не тільки для діагностики їхнього функціонального та гормонального стану, а й для виявлення доклінічних ознак різних патологій (Tsiligianni et al., 2001; Sakai et al., 2004; Kim et al., 2014).

За даними (Stravskyi, 2011; Gonchar, 2014), клітинний склад епітелію сливової оболонки піхви впродовж статевого циклу представлений проміжними i поверхневими ороговілими і незроговілими клітинами.

Метою роботи було вивчення цитології вагінальної слизу при симптоматичній формі неплідності корів.

\section{Матеріал і методи дослідження}

Дослідження проводили протягом листопадагрудня 2014 р. на 5 групах корів 4-5-річного віку по 6 голів у кожній, вагою 500-600 кг, середньою продуктивністю 7500 кг молока за лактацію.

Контрольними були корови на 18-24 день після отелення і в стадії гальмування статевого циклу, дослідними - за сумісного перебігу гіпотонії матки та гіпофункції яєчників, наявності персистентного жов- того тіла і субклінічного хронічного ендометриту, кісти та персистентного жовтого тіла яєчника.

Відбитки виготовляли зі слизової оболонки каудального відділу шийки, бокової поверхні піхви і дорсальної стінки присінку піхви. Фарбування мазків проводили гематоксиліном та еозином. Дослідження проводили 3 допомогою мікроскопа, фотографували цифровою камерою.

Цитологічний склад вагінального слизу визначали за кількістю поверхневих, проміжних і парабазальних епітеліальних клітин та станом їх ядер.

Результати дослідження.

Нами досліджено і порівняно цитологічну картину відбитків зі слизової оболонки шийки матки, піхви, присінку піхви в корів за різного стану організму (табл. 1).

Відповідно до класифікації клітинного складу мазків зі слизової оболонки піхви розрізняють 4 реакції, за якими визначають ступінь насичення організму естрогенами.

Перша реакція свідчить про сильно виражену естрогенну недостатність, коли у мазку переважають базальні та проміжні клітини і відсутні елементи поверхневого епітелію.

Друга реакція характеризується наявністю клітин проміжного типу, присутність базальних і поверхневих. Такий тип мазків вказує на виражену естрогенну недостатність.

За третього типу реакції, при незначній естрогенній недостатності в мазках переважають поверхневі базофільні клітини 3 малим ядром, базальні клітини відсутні або одиничні.

Четвертий тип реакції за переважанням поверхневих ацидофільних клітин з вираженим пікнозом ядер, базофільних 3 малим ядром, незначною кількістю парабазальних клітин властивий для гіперестрогенної насиченості організму.

За субклінічного хронічного ендометриту в мазках зі слизової оболонки піхви присутні базальні (32$41 \%$ ), що розташовані пластами, парабазальні (6$22 \%$ і поверхневі (5-21\%) клітини, але найбільше проміжних (37-66\%), та голі ядра нейтрофілів (табл. 1).

За даними Dadarwal D., Palmer C. \& Griebel P. (2017), цитологічний склад піхвового слизу протягом післяотельного періоду змінюється залежно від його перебігу. За фізіологічного стану в мазках переважають поверхневі клітини (49-60\%), а при післяотельному ендометриті - проміжні клітини (40-55 \%). 
За гострого післяродового ендометриту в мазках із піхви виявляли клітини базального шару з гіперхромними ядрами і набухлою базофільною цитоплазмою, проміжні клітини і поверхневі, в малій кількості базальні та парабазальні.
Важливе діагностичне значення має стан ядер епітеліальних клітин: поверхневі клітини з ядром в стані рекситу при ендометриті - 1,8 \%, проміжні 3 нормальним ядром - $55 \%$, а 3 рекситом ядра - $10 \%$, парабазальні з нормальним ядром - 11,6 \% (Adnane et al., 2017).

Таблиця 1

Клітинний склад слизової оболонки статевих органів корів за різного стану організму, $\mathrm{n}=30$

\begin{tabular}{|c|c|c|c|}
\hline \multirow{2}{*}{ Групи корів } & \multicolumn{3}{|c|}{ Характеристика епітелію } \\
\hline & Шийка матки & Піхва & Присінок піхви \\
\hline $\begin{array}{l}\text { I - К } \\
\text { Після отелення 18- } \\
24 \text { день, } \mathrm{n}=6\end{array}$ & $\begin{array}{l}\text { Одиночні поверхневі та } \\
\text { парабазальні клітини, появ- } \\
\text { ляються проміжні } \\
\end{array}$ & $\begin{array}{l}\text { Переважають поверхневі клітини } 3 \\
\text { пікнотичними ядрами, значно менше } \\
\text { парабазальних та проміжних клітин }\end{array}$ & $\begin{array}{l}\text { Поверхневі клітини, по } \\
\text { декілька разом }\end{array}$ \\
\hline $\begin{array}{lr}\mathbf{I I}-\mathbf{K} & \\
\text { Стадія } \quad \text { гальмування } \\
\text { статевого циклу, } \mathrm{n}=6\end{array}$ & $\begin{array}{l}\text { Переважають парабазальні і } \\
\text { проміжні клітини, зібрані в } \\
\text { пучки }\end{array}$ & $\begin{array}{l}\text { Присутні всі клітини. Поодинокі } \\
\text { поверхневі }\end{array}$ & $\begin{array}{l}\text { Присутні всі клітини. } \\
\text { Поодинокі поверхневі }\end{array}$ \\
\hline $\begin{array}{l}\text { III - Д } \\
\text { Гіпофункція яєчни- } \\
\text { ків і гіпотонія матки, } \\
\mathrm{n}=6\end{array}$ & $\begin{array}{l}\text { Переважають парабазальні } \\
\text { та проміжні клітини }\end{array}$ & $\begin{array}{l}\text { Присутні парабазальні клітини по } \\
\text { декілька у полі зору базальні та } \\
\text { проміжні }\end{array}$ & $\begin{array}{l}\text { Небагато базальних, пара- } \\
\text { базальних та двоядерних } \\
\text { клітин. Спостерігали цито- } \\
\text { ліз та пікноз ядер }\end{array}$ \\
\hline $\begin{array}{l}\text { IV-Д } \\
\text { Субклінічний хроні- } \\
\text { чний ендометрит і } \\
\text { ПЖТ, } \mathrm{n}=6\end{array}$ & $\begin{array}{l}\text { Парабазальні } \\
\text { клітини }\end{array}$ & $\begin{array}{l}\text { Присутні всі клітини. Переважають } \\
\text { парабазальні та проміжні }\end{array}$ & $\begin{array}{l}\text { Переважають парабазальні, } \\
\text { трапляються базальні, } \\
\text { проміжні, одиночні повер- } \\
\text { хневі клітини }\end{array}$ \\
\hline $\begin{array}{l}\mathbf{V}-\text { Д } \\
\text { Фолікулярна } \quad \text { кіста } \\
\text { яєчника і ПЖТ, } \mathrm{n}=6\end{array}$ & $\begin{array}{l}\text { Переважають парабазальні } \\
\text { проміжні, одиночні поверх- } \\
\text { неві клітини }\end{array}$ & $\begin{array}{l}\text { Переважають проміжні парабазаль- } \\
\text { ні клітини, поодинокі базальні }\end{array}$ & $\begin{array}{l}\text { Пласти парабазальних } \\
\text { клітин. Поодинокі проміж- } \\
\text { ні клітини } \\
\end{array}$ \\
\hline
\end{tabular}

При гіпофункції яєчників в піхвових мазках виявляли нейтрофіли, вакуолі в ядрах проміжних клітин (44-56 \%), базофільні клітини (30-43\%), поверхневі (20-21\%), парабазальні (3-6\%). За гіпофункції яєчників базальних клітин було (3-43 \%), парабазальних (3-6\%), проміжних (44-56\%), поверхневих (20$21 \%)$, а при двобічній (12-26\%) - (4-5\%), (36-55\%) та $(30-33 \%)$.

Встановлено, що циліндричні клітини в нормі розташовуються невеликими купками у вигляді смужок або сотоподібно. Їхня форма витягнута, ядра розміщенні ексцентрично. Вони рідко виявляються у відбитках із каудальної ділянки шийки матки.

Проміжні клітини порівняно великі, полігональні, ядра міхурцеві, цитоплазма складчаста.

Парабазальні клітини маленькі, овальні або округлі, ядро велике міхурцеподібне, цитоплазма оксифільна.

За функціонального стану організму клітини із шийки матки плоскі. Окрім них, у препараті містяться одиничні лейкоцити зі світлою цитоплазмою без ознак фагоцитозу. За структурою вони подібні до клітин мазків зі слизової оболонки піхви.

Під час тічки в мазках переважають проміжні та поверхневі клітини і лейкоцити.

В фолікулярну проліферативну фазу, передтічкову збільшується число поверхневих клітин.

Овуляторна фаза характеризується вираженим дозріванням клітин, вони плоскі, розташовуються порізно.
Секреторна або прогестеронова фаза, на 6-10 день після овуляції, проявляється збільшенням кількості клітин зі складчастою цитоплазмою, згрупованих у купки.

\section{Висновки}

1. За субклінічного хронічного ендометриту в мазках зі слизової оболонки піхви присутні базальні (32$41 \%$ ), що розташовані пластами, парабазальні (22$6 \%$ ) і поверхневі клітини (5-21\%), але найбільше проміжних (37-та $6 \%$ ), та голі ядра нейтрофілів.

2. За гострого післяродового ендометриту в мазках iз піхви виявляли клітини базального шару з гіперхромними ядрами і набухлою базофільною цитоплазмою, проміжні клітини і поверхневі та в малій кількості базальні й парабазальні.

3. При гіпофункції яєчників в піхвових мазках виявляли нейтрофіли, базофільні клітини (30-43\%), поверхневі (20-21\%), парабазальні (3-6\%), вакуолі в ядрах проміжних клітин складали (44-56 \%). За гіпофункції яєчників базальних клітин було (3-43\%), парабазальних (3-6\%), проміжних (44-56 \%), поверхневих (20-21\%), а при двобічній гіпофункції яєчників $(12-26 \%)-(4-5 \%),(36-55 \%)$ та (30-33\%) відповідно. 


\section{References}

Adnane, M., Chapwanya, A., Kaidi, R., Meade, K. G. \& O'Farrelly, C. (2017). Profiling inflammatory biomarkers in cervico-vaginal mucus (CVM) postpartum: potential early indicators of bovine clinical endometritis. Theriogenology, 103, 117-122. doi: 10.1016/j.theriogenology.2017.07.039.

Azawi, O. I. (2008). Postpartum uterine infection in cattle. Anim Reprod Sci, 105(3-4), 187-208. doi: 10.1016/j.anireprosci.2008.01.010.

Becher, N., Adams Waldorf, K., Hein, M. \& Uldbjerg, N. (2009). The cervical mucus plug: structured review of the literature. Acta Obstet Gynecol Scand, 88, 502513. doi: $10.1080 / 00016340902852898$.

Berry, E. A. (2002). The Effect of Selective Dry Cow Treatment on New Intramammary Infections. Journal of Dairy Science, 85(1), 112-121. doi: 10.3168/jds.S0022- 0302(02)74059-9.

Causey, R. C. (2007). Mucus and the mare: how little we know. Theriogenology, 68(3), 386-394. doi: 10.1016/j.theriogenology.2007.04.011.

Dadarwal, D., Palmer, C., \& Griebel, P. (2017). Mucosal immunity of the postpartum bovine genital tract. Theriogenology, 104, 62-71. doi: 10.1016/j.theriogenology. 2017.08.010.

Foley, C., Chapwanya, A., Callanan, J. J., Whiston, R., Miranda-CasoLuengo, R., Lu, J., Meijer, W. G., Lynn, D. J., O' Farrelly, C., \& Meade, K. G. (2015). Integrated analysis of the local and systemic changes preceding the development of post-partum cytological endometritis. BMC Genomics, 16, 811. doi: 10.1186/s12864-015-1967-5.

Gonchar, A. O. (2014). Doslidzenia cervikalnogo sluzy vusokoprodyktuvnuh koriv. Nakovui visnyk LNUVMB imeni S. Z. Gzuckogo, 16, 3(60), 63-73 (in Ukrainian).

Hoorens, P. R., Rinaldi, M., Li, R.W., Goddeeris, B., Claerebout, E., Vercruysse, J., \& Geldhof, P. (2011). Genome wide analysis of the bovine mucin genes and their gastrointestinal transcription profile. BMC Genomics, 12, 140. doi: 10.1186/1471-2164-12-140.

Hryshchuk, H. P., \& Revunets, A. S. (2017). Zastosuvannia tkanynnoi terapii $\mathrm{u}$ borotbi $\mathrm{z}$ symptomatychnoiu neplidnistiu koriv. Visnyk ZhNAEU, 2(63), 37-44 (in Ukrainian).

Karstrup, C. C., Klitgaard, K., Jensen, T. K., Agerholm, J. S., \& Pedersen, H. G. (2017). Presence of bacteria in the endometrium and placentomes of pregnant cows. Theriogenology, 99, 41-47. doi: 10.1016/j.theriogenology.2017.05.013.

Kasimanickam, R., Duffield, T. F., Foster, R. A., Gartley, C. J., Leslie, K. E., Walton, J. S. \& Johnson, W. H. (2004). Endometrial cytology and ultrasonography for the detection of subclinical endometritis in postpartum dairy cows. Theriogenology, 62, 9-23. doi: 10.1016/j.theriogenology.2003.03.001.

Kim, I. H., Kang, H. G., Jeong, J. K., Hur, T. Y., \& Jung, Y. H. (2014). Inflammatory cytokine concentrations in uterine flush and serum samples from dairy cows with clinical or subclinical endometritis. Theriogenology, 82(3), 427-432. doi: 10.1016/j.theriogenology.2014. 04.022 .

Sakai, M., Ishiyama, A., Tabata, M., Sasaki, Y., Yoneda, S., Shiozaki, A., \& Saito, S. (2004). Relationship between cervical mucus interleukin- 8 concentrations and vaginal bacteria in pregnancy. Am J Reprod Immunol., 52, 106-112. doi: 10.1111/j.1600-0897.2004.00203.x.

Stravskyi, I. S. (2009). Diagnostuchne znachenia cutologichnogo metodu doslidgenia mazkiv sluzovoi pihvu koriv y pisliarodovui period. Nakovui visnyk LNUVMB imeni S. Z. Gzuckogo, 2(41), 314-317 (in Ukrainian)

Stravskyi, I. S. (2011). Pokaznyku lohyi koriv pru sybinvolycii matku. Veterynarna biotehnologia, 20, 185190 (in Ukrainian).

Tsiligianni, T., Karagiannidis, A., Brikas, P., \& Saratsis, P. (2001). Chemical properties of bovine cervical mucus during normal estrus and estrus induced by progesterone and/or PGF2 $\alpha$. Theriogenology, 56(1), 4150. doi: 10.1016/S0093-691X(01)00541-6.

Wagener, K., Gabler, C., \& Drillich, M. (2017). A review of the ongoing discussion about definition, diagnosis and pathomechanism of subclinical endometritis in dairy cows. Theriogenology, 94, 21-30. doi: 10.1016/j.theriogenology.2017.02.005.

Williams, E. J., Fischer, D. P., Pfeiffer, D. U., England, G. C., Noakes, D. E., Dobson, H., \& Sheldon, I. M. (2005). Clinical evaluation of postpartum vaginal mucus reflects uterine bacterial infection and the immune response in cattle. Theriogenology, 63(1), 102-117. doi: 10.1016/j.theriogenology.2004.03.017.

Zegels, G., Van Raemdonck, G. A., Tjalma, W. A., \& Van Ostade, X. W. (2010). Use of cervicovaginal fluid for the identification of biomarkers for pathologies of the female genital tract. Proteome Sci, 8, 63. doi: 10.1186/1477-5956-8-63. 